Мельник В.С., Горзов Л.Ф., Білищук Л.М., Зомбор К.В., Ратушний Р.І.

\title{
Лікування атопічного хейліту у підлітків з зубощелепними аномаліями
}

\author{
ДВНЗ «Ужгородський національний університет», м. Ужгород, Україна \\ volodymyr.melnyk@uzhnu.edu.ua, liudmyla.horzov@uzhnu.edu.ua, \\ liubov.bilyschuk@uzhnu.edu.ua, kateryna.zombor@uzhnu.edu.ua,rus.ratus.rus@gmail.com
}

\begin{abstract}
Мельник В.С., Горзов Л.Ф.,
Билыщук Л.М., Зомбор К.В., Ратушный Р.И.

Лечение атопического хейлита у подростков с зубочелюстными аномалиями

ДВНЗ «Ужгородский национальный университет», г. Ужгород, Украина
\end{abstract}

\section{Вступ}

Стан здоров'я підлітків - це не тільки показник існуючого соціально-економічного та суспільного розвитку країни, а й важливий індикатор майбутнього трудового, економічного, культурного потенціалу суспільства $[1,11]$.

Зубощелепні аномалії є одним 3 компонентів, які формують стоматологічний статус індивідуума, тим самим визначаючи і загальний стан організму. Аналіз спостережень стоматологів у світі показав, що більше $80 \%$ населення земної кулі до 25 років мають аномалію розташування зубів, виражену в тій чи іншій мірі. I від 35 до 60\% з цього числа вимагають втручання ортодонта [12].

Одним з найбільш частих супутніх захворювань у підлітків з зубощелепними аномаліями є хейліт. За даними літератури при обстеженні 100 дітей у віці від 12 до 15 років встановлено, що у дітей, які мають зубощелепні аномалії, хейліт зустрічається значно частіше $(66,0 \%)$, ніж у дітей без патології зубощелепної системи (28,0\%) [2].

Хейліти представляють собою групу різноманітних по етіології, патогенезу i клінічній картині хронічних захворювань червоної облямівки губ. Поширеність окремих видів хронічних, часто рецидивуючих самостійних захворювань червоної облямівки губ серед різних груп населення коливається в межах від 3,9 до $26,4 \%$. Найбільш поширеним $\epsilon$ атопічний хейліт $[4,9]$. Серед факторів, які сприяють розвитку даного захворювання, виділяють порушення архітектоніки губ, шкідливі звички: облизування і покусування губ та причини, які сприяють виникненню хейлітів у дітей: ротове і змішане дихання, патологія прикусу, короткі вуздечки губ [6].

Хейліт має суттєвий вплив на самопочуття i соціальну активність хворих, погано піддається стандартним методам терапії, а у деяких хворих протікає у вигляді моносимптому атопічного дерматиту. Періоральні
Melnyk V.S., Horzov L.F., Bilyshchuk LM., Zombor K.V., Ratushniy R.I. Treatment of atopic cheilitis in adolescents with dentoalveolar anomalies

SU «Uzhhorod National University», Uzhhorod, Ukraine ураження сприяють формуванню у дітей депресії, ускладнюють соціальну адаптацію, що є фактором стресу у підлітків, впливають на рівень якості їх життя $[7,10]$.

Мета дослідження - розробка та впровадження в практику мазі для лікування атопічного хейліту у підлітків з зубощелепними аномаліями.

\section{Матеріали та методи}

Проведено стоматологічне обстеження 139 підлітків у віці від 12 до 15 років. 3 них 67 юнаків і 72 дівчат. Визначали поширеність зубощелепних аномалій та потребу в їх лікуванні, поширеність захворювань червоної облямівки губ. Для визначення ступеня важкості аномалій та потребу в лікуванні застосовували рекомендований BOO3 естетичний стоматологічний індекс DAI (N.C. Cons, 1986). Також визначали компонент стоматологічного статусу DHC індексу потреби в ортодонтичній допомозі IOTN (Shaw W. C., Evans R., 1987) [5].

\section{Результати дослідження та їх обговорення}

Поширеність зубощелепних аномалій склала 73,2\% (73,24\% серед дівчат, 73,11\% серед юнаків). Структура зубощелепних аномалій виглядає наступним чином: аномалії окремих зубів були діагностовані у 6,51\% обстежених, аномалії зубних рядів у $21,72 \%$, аномалії прикусу спостерігали у 7,54\% підлітків, поєднані аномалії були зареєстровані у 64,23\% обстежених.

Показники естетичного індексу DAI нижче 25, що свідчать про наявність мінімальних порушень прикусу, визначені у 78,54\% обстежених. Значення DAI, рівні 26-30, інтерпретуються як явне порушення прикусу, внаслідок чого необхідно вибіркове лікування, виявлені у 13,73\% підлітків. За результатами дослідження, значення DAI від 31 до 35, характерні для важких порушень прикусу, зустрічаються у 4,86\% дітей старшого віку. 
Показники естетичного індексу від 36 і вище, що визначають наявність дуже важких порушень прикусу і вимагають обов'язкового лікування, спостерігалися у $2,86 \%$. Відповідно до інтерпретації показників компонента DHC індексу IOTN 31,69\% обстежених не потребують лікуванні (1 клас), 44,85\% мають низьку потребу (2 клас), для $15,74 \%$ підлітків визначена середня ступінь потреби (3 клас). 6,58\% обстежених мають високу потребу (4 клас), i тільки для $1,14 \%$ існує дуже висока потреба в ортодонтичному лікуванні (5 клас).

В результаті проведеного обстеження поширеність захворювань губ діагностували у 23,8\%, а прикушення щік виявили у 3,9\% підлітків. Лейкоплакія, червоний плоский лишай та інші патології були виявлені в 2,2\% випадках. Атопічний хейліт діагностували досить часто - 13,4\% обстежених, метеорологічний хейліт 9,8\%, у 2,9\% дітей старшого віку реєстрували хронічні тріщини губ і у $0,7 \%$ були зареєстровані папіломи, ретенційні кісти, тріщини кутів рота.

Пацієнти, в яких діагностували зубощелепні аномалії та атопічний хейліт скаржилися на сухість i печіння губ, біль при відкриванні рота, розмові, прийомі їжі, шкіра в кутах рота була набрякла, покрита лусочками, гіперемована, мали місце тріщини.

Розроблена та апробована (на 46 пацієнтах) мазь для лікування атопічного хейліту, до складу якої входила настоянка лікарських рослин в якості активної речовини та вазелін-ланолінова суміш $(8: 2)$ в якості основи (подана заявка на корисну модель).

Мазь є м'якою лікарської формою, призначеною для нанесення на шкіру, що складається зі збору лікарських рослин, що містить квітки календули Calendula officinalis L., траву водяного перцю - Polygoni hydropiperis herba, траву звіробою - (Нуреricum perforatum L.), квітки шавлії - Salvia, квітки ромашки - Matricaria chamomilla). Основа забезпечує необхідну масу мазі i, таким чином, належну концентрацію лікарських речовин, м'яку консистенцію, необхідну для зручності нанесення на шкіру. Хімічна інертність основи гарантує відсутність взаємодії з лікарськими речовинами, зміни під дією зовнішніх факторів (повітря, світло, волога, температура), отже, забезпечує стабільність мазі $[3,8]$.

Компоненти, які входять до складу мазі збалансовані таким чином, щоб досягти найвищого терапевтичного ефекту при лікуванні хейлітів у дітей та підлітків з зубощелепними аномаліями. При зменшенні або збільшенні вмісту компонентів у мазі виникає ризик виникнення побічних ефектів. Підбір рослинної сировини в композиції обумовлений терапевтичними властивостями рослинних компонентів, які входять до ії складу.

Завдяки такому поєднанню рослинної сировини забезпечується терапевтичний ефект при лікуванні хейлітів у дітей та підлітків з зубощелепними аномаліями, зниження ризику виникнення побічної дії, а також лікарська форма, яка є зручною для використання дітьми та підлітками.

Мазь наносили на уражену ділянки шкіри тонким шаром 2 рази на день (ранком та ввечері) після їди та утримували на губах протягом однієї години. Через добу після застосування мазі припинялися біль, свербіння, зменшувалася гіперемія, набряк. Епітелізація ураженої поверхні губ відбувалася на 8-10 день.

\section{Висновки}

Вивчення поширеності зубощелепних аномалій, потребу в їх лікуванні, поширеності хейлітів у підлітків привело до розробки мазі для лікування атопічного хейліту у пацієнтів 3 зубощелепними аномаліями, що складається 3 лікарських рослин в якості активної речовини та вазелін-ланолінова суміш $(8: 2)$ в якості основи, яка має виражену антимікробну, ранозагоювальну і кератопластичну дію, а також сприяє скороченню термінів лікування.

\section{Література}

1. Головко Н.В. Профілактика зубощелепних аномалій / Н.В.Головко.- Вінниця: Нова Книга, 2005. - 252 с.

2. Горбатова Л.Н. Атопический хейлит у детей: факторы риска и клинические симптомы / Л.Н.Горбатова // Стоматология. - 2000. - №3. - С. 49-50.

3. Державний реєстр сортів рослин, придатних для поширення в Україні на 2015 рік [Електронний ресурс]. Режим доступу http://www.vet.gov.ua/sites/default/files/Reestr-29-04-2015.pdf.

4. Елизарова В. М. Атопический хейлит при атопическом дерматите у детей / В.М.Елизарова, В.В.Репина // Фарматека. - 2013. - № 2-13. - С. 15-17.

5. Клінічні та спеціальні методи обстеження у дитячій стоматології [Електронний ресурс]. - Режим доступу: http://smile-center.com.ua/ru/articles/klinichni-ta-specmetody-obstezhennya-doslidzhennya-u-dyt-stomat.

6. Коваль Н.И. Заболевания губ. Клиническая картина. Диагностика. Дифференциальная диагностика. Лечение. Профилактика: учеб. пособие / Н.И. Коваль, А.Ф. Несин, Е.А. Коваль; под ред. проф. А.В. Борисенко. К.: ВСИ «Медицина», 2013. - 344 с.

7. Кулигіна В.М. Функціональні порушення, шкідливі звички та зміни архітектоніки губ при атопічному хейліті в дітей різного віку / В.М. Кулигіна, М.В. Стремчук // Современная стоматология. - 2014. - №4 (73). - С. 58-63.

8. Леженко Г.O. Використання зволожувального крему «Aqualan L» у терапії атопічного дерматиту у дітей / Г.О. Леженко // Современная педиатрия. - 2010. - №3 (31). - С. 135-136.

9. Мочульська О.М. Поширеність атопічного дерматиту в дітей, особливості етіології та патогенезу на сучасному етапі / О.М. Мочульська // Актуальні питання педіатрії, акушерства та гінекології. - 2015. - №1. - С. 94-98. 
10. Савичук Н.О. Особливості клініки та фактори ризику виникнення атопічного хейліту / Н.О. Савичук, М.М. Соломонюк // Ліки України. - 2004. - №1. - С. 79-81.

11. Терапевтическая стоматология детского возраста / [Л.А. Хоменко, Л.П. Кисельникова, Н.И. Смоляр и др.]; под ред. проф. Л.А. Хоменко, проф. Л.П. Кисельниковой. - К.: Книга плюс, 2013. - 864 с.

12. Фліс П.С. Ортодонтія. Зубо-щелепні аномалії та деформації. Dentognathic Anomalies and Deformation // П.С. Фліс, Г.П. Леоненко, В.В. Філоненко, Н.М. Дорошенко. - К.: ВСВ «Медицина», 2015. - 176 с.

\section{References}

1. Holovko N.V. Profilaktyka zuboshchelepnykh anomalii [Prevention of dentoalveolar anomalies] / N.V.Holovko. Vinnytsia: Nova Knyha, 2005. - 252 s. (Ukr).

2. Gorbatova L.N. Atopicheskij khejlit u detej: faktory` riska i klinicheskie simptomy` [Atopic cheilitis in children: risk factors and clinical symptoms]/ L.N.Gorbatova // Stomatologiya. - 2000. - \#3. - S. 49-50. (Rus).

3. Derzhavnyi reiestr sortiv roslyn, prydatnykh dlia poshyrennia v Ukraini na 2015 rik [State register of plant varieties suitable for distribution in Ukraine for 2015] [Elektronnyi resurs]. - Rezhym dostupu http://www.vet.gov.ua/sites/default/files/Reestr29-04-2015.pdf (Ukr).

4. Elizarova V. M. Atopicheskij khejlit pri atopicheskom dermatite u detej [Atopic cheilitis with atopic dermatitis in children] / V.M.Elizarova, V.V.Repina // Farmateka. - 2013. - \# 2-13. - S. 15-17. (Rus).

5. Klinichni ta spetsialni metody obstezhennia u dytiachii stomatolohii [Clinical and special examination methods in pediatric dentistry] [Elektronnyi resurs]. - Rezhym dostupu: http://smile-center.com.ua/ru/articles/klinichni-ta-specmetody-obstezhennyadoslidzhennya-u-dyt-stomat http://www.vet.gov.ua/sites/default/files/Reestr-29-04-2015.pdf (Ukr).

6. Koval N.I. Zabolevaniya gub. Klinicheskaya kartina. Diagnostika. Differenczial naya diagnostika. Lechenie. [Diseases of the lips. The clinical picture. Diagnostics. Differential diagnosis. Treatment]Profilaktika: ucheb. posobie / N.I. Koval', A.F. Nesin, E.A. Koval; pod red. prof. A.V. Borisenko. - K.: VSI «Mediczina», 2013. - 344 s. (Rus).

7. Kulyhina V.M. Funktsionalni porushennia, shkidlyvi zvychky ta zminy arkhitektoniky hub pry atopichnomu kheiliti $\mathrm{v}$ ditei riznoho viku [Functional disorders, bad habits and changes in lip architectonics in atopic cheilitis in children of all ages] / V.M. Kulyhina, M.V. Stremchuk // Sovremennaia stomatolohyia. - 2014. - №4 (73). - S. 58-63. (Ukr).

8. Lezhenko H.O. Vykorystannia zvolozhuvalnoho kremu «Aqualan L» u terapii atopichnoho dermatytu u ditei [The use of Aqualan L moisturizer in the treatment of atopic dermatitis in children] / H.O. Lezhenko // Sovremennaia pedyatryia. - 2010. №3 (31). - S. 135-136. (Ukr).

9. Mochulska O.M. Poshyrenist atopichnoho dermatytu v ditei, osoblyvosti etiolohii ta patohenezu na suchasnomu etapi [Prevalence of atopic dermatitis in children, features of etiology and pathogenesis at the present stage] / O.M.Mochulska // Aktualni pytannia pediatrii, akusherstva ta hinekolohii. - 2015. - №1. - S. 94-98. (Ukr).

10. Savychuk N.O. Osoblyvosti kliniky ta faktory ryzyku vynyknennia atopichnoho kheilitu [Clinical features and risk factors for atopic cheilitis] / N.O. Savychuk, M.M. Solomoniuk // Liky Ukrainy. - 2004. - №1. - S. 79-81. (Ukr).

11. Terapevticheskaya stomatologiya detskogo vozrasta [Pediatric Therapeutic Dentistry]/ [L.A. Khomenko, L.P. Kisel`nikova, N.I. Smolyar i dr.]; pod red. prof. L.A. Khomenko, prof. L.P. Kisel’nikovoj. - K.: Kniga plyus, 2013. - 864 s. (Rus).

12. Flis P.S. Ortodontiia. Zubo-shchelepni anomalii ta deformatsii. Dentognathic Anomalies and Deformation // P.S. Flis, H.P. Leonenko, V.V. Filonenko, N.M. Doroshenko. - K.: VSV «Medytsyna», 2015. - 176 s. (Eng).

Дата надходження рукопису до редакції: 14.02 .2020 р.

Мета дослідження - розробка та впровадження в практику мазі для лікування атопічного хейліту у підлітків 3
зубощелепними аномаліями.

Матеріали та методи. Проведено стоматологічне обстеження 139 підлітків у віці від 12 до 15 років. 3 них 67 юнаків і 72 дівчат. Визначали поширеність зубощелепних аномалій та потребу в їх лікуванні, поширеність захворювань червоної облямівки губ.

Результати. В результаті проведеного обстеження поширеність захворювань губ діагностували у 23,8\%, а прикушення щік виявили у 3,9\% підлітків. Атопічний хейліт діагностували досить часто - 13,4\% обстежених, метеорологічний хейліт 9,8\%, у 2,9\% дітей старшого віку реєстрували хронічні тріщини губ і у 0,7\% були зареєстровані папіломи, ретенційні кісти, тріщини кутів рота. Пацієнти, в яких діагностували зубощелепні аномалії та атопічний хейліт скаржилися на сухість і печіння губ, біль при відкриванні рота, розмові, прийомі їжі, шкіра в кутах рота була набрякла, покрита лусочками, гіперемована, мали місце тріщини. Розроблена та апробована мазь для лікування атопічного хейліту, до складу якої входила настоянка лікарських рослин в якості активної речовини та вазелін-ланолінова суміш $(8: 2)$ в якості основи.

Висновки. Вивчення поширеності зубощелепних аномалій, потребу в їх лікуванні, поширеності хейлітів у підлітків привело до розробки мазі для лікування атопічного хейліту у пацієнтів з зубощелепними аномаліями, що складається 3 лікарських рослин в якості активної речовини та вазелін-ланолінова суміш (8:2) в якості основи, яка має виражену антимікробну, ранозагоювальну і кератопластичну дію, а також сприяє скороченню термінів лікування.

Ключові слова: зубощелепні аномалії, атопічний хеліт, діти, мазь. 
Цель исследования - разработка и внедрение в практику мази для лечения атопического хейлита у подростков с зубочелюстными аномалиями.

Материалы и методы. Проведено стоматологическое обследование 139 подростков в возрасте от 12 до 15 лет. Из них 67 юношей и 72 девушек. Определяли распространенность зубочелюстных аномалий и потребность в их лечении, распространенность заболеваний красной каймы губ.

Результаты. В результате проведенного обследования распространенность заболеваний губ диагностировали у $23,8 \%$, а прикусывания щек обнаружили в 3,9\% подростков. Атопический хейлит диагностировали довольно часто - $13,4 \%$ обследованных, метеорологический хейлит 9,8\%, в 2,9\% детей старшего возраста регистрировали хронические трещины губ и у $0,7 \%$ были зарегистрированы папилломы, ретенционные кисты, трещины углов рта. Пациенты, у которых диагностировали зубочелюстные аномалии и атопический хейлит жаловались на сухость и жжение губ, боль при открывании рта, разговоре, приеме пищи, кожа в углах рта была отечная, покрыта чешуйками, гиперемирована, имели место трещины. Разработана и апробирована мазь для лечения атопического хейлита, в состав которой входила настойка лекарственных растений в качестве активного вещества и вазелин-ланолиновой смесь (8: 2) в качестве основы.

Выводы. Изучение распространенности зубочелюстных аномалий, потребность в их лечении, распространенности хейлитов у подростков привело к разработке мази для лечения атопического хейлита у пациентов с зубочелюстными аномалиями, состоящий из лекарственных растений в качестве активного вещества и вазелин-ланолиновой смеси (8: 2) в качестве основы, которая обладает выраженным антимикробным, ранозаживляющим и кератопластическое действие, а также способствует сокращению сроков лечения.

Ключевые слова: зубочелюстные аномалии, атопический хелит, дети, мазь.

The purpose of the study is to develop and put into practice ointments for the treatment of atopic cheilitis in adolescents with dentoalveolar anomalies.

Materials and methods. Dental examination of 139 adolescents aged 12 to 15 years was performed. Of these, 67 boys and 72 girls. The prevalence of dental anomalies and the need for their treatment were determined, the prevalence of red lip disease.

Results. As a result of the survey, the prevalence of lip diseases was diagnosed in $23.8 \%$, and cheek bites were found in $3.9 \%$ of adolescents. Atopic cheilitis was diagnosed quite often $-13.4 \%$ of the surveyed, meteorological cheilitis $9.8 \%, 2.9 \%$ of older children had chronic lip cracks and $0.7 \%$ had papillomas, retinal cysts, cracks in the corners of the mouth. Patients diagnosed with dental anomalies and atopic cheilitis complained of dryness and burning of the mouth, pain when opening the mouth, talking, eating, the skin in the corners of the mouth was swollen, covered with scales, hyperemic, cracks. An ointment for the treatment of atopic cheilitis was developed and tested.

Conclusions. The study of the prevalence of dental anomalies, the need for their treatment, the prevalence of cheilitis in adolescents led to the development of ointments for the treatment of atopic cheilitis in patients with dental anomalies, consisting of medicinal plants as the active substance and Vaseline-lanolin mixture as 8:2, which has a pronounced antimicrobial, wound healing and keratoplastic effect, and also helps to reduce treatment time.

Key words: dentoalveolar anomalies, atopic chelitis, children, ointment.

Конфлікт інтересів: відсутній.

Conflicts of interest: authors have no conflicts of interest to declare.

\section{Відомості про авторів}

Мельник Володимир Семенович - к.мед.н., доцент, зав. кафедри дитячої стоматології ДВНЗ «Ужгородський національний університет»; Ужгород, Україна, 88000, вул. Університетська, 16 а.

+380 (50) 606-36-04, volodymyr.melnyk@uzhnu.edu.ua.

Горзов Людмила Федорівна - к.мед.н., доцент, доцент кафедри дитячої стоматології ДВНЗ «Ужгородський національний університет»; Ужгород, Україна, 88000, вул. Університетська, 16а.

+380(50) 762-61-29, liudmyla.horzov@uzhnu.edu.ua.

Білищук Любов Миколаївна - к.мед.н., доцент кафедри дитячої стоматології ДВНЗ «Ужгородський національний університет»; Ужгород, Україна, 88000, вул. Університетська, 16а.

+380 (95) 086-91-98, liubov.bilyschuk@uzhnu.edu.ua.

Зомбор Катерина Володимирівна - к.мед.н., доцент кафедри дитячої стоматології ДВНЗ «Ужгородський національний університет»; Ужгород, Україна, 88000, вул. Університетська, 16а.

+380(50) 901-59-05, kateryna.zombor@uzhnu.edu.ua.

Ратушний Руслан Ігорович - аспірант кафедри ортопедичної стоматології ДВНЗ «Ужгородський національний університет»; Ужгород, Україна, 88000, вул. Університетська, 16а.

+380 (68) 203-31-91, rus.ratus.rus@gmail.com. 